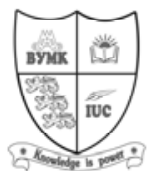

European Journal of Tourism Research

http://ejtr.vumk.eu

\title{
Post-war tourism and the imaginative geographies of Bosnia and Herzegovina and Croatia
}

\author{
Nicholas A. Wise ${ }^{1}$ \\ Received: 22/06/2010 Accepted: 28/12/2010
}

\begin{abstract}
${ }^{1}$ Department of Geography, Kent State University, 413 McGilvery Hall, Kent, OH 44242, Phone:(330) 672-2045 Fax: 330 672-4304, e-mail: nwise5@kent.edu
\end{abstract}

\begin{abstract}
In the early 1990s Bosnia and Herzegovina and Croatia were spaces of conflict. The media presented much of what occurred during the war years, constructing our imaginative geographies. This study determines the role of discourse for understanding contemporary image (re)constructions concerning post-war countries. Acknowledging the significance of tourism, this economic sector acts as a catalyst to promote and highlight image transitions. To contribute to the growing literature on post-war tourism, a three-fold typology is presented to position these countries as landscape remembrance, fading memory or replacing memory. This work draws from newspaper articles and official tourism websites as modes of discourse positioned to convey information and details that establish imaginative expressions of places to support the proposed typologies. A discourse analysis of both textual and visual content is interpreted to determine how these sources construct the three-fold typology and (re)create meanings and images of Bosnia and Herzegovina and Croatia.
\end{abstract}

(c) 2011 International University College. All rights reserved

Keywords: post-war tourism, imaginative geographies, discourse, memory, Bosnia and Herzegovina, Croatia

Citation: Wise, N.A. (2011) Post-war tourism and the imaginative geographies of Bosnia and Herzegovina and Croatia. European Journal of Tourism Research 4(1), pp. 5-24

\section{Introduction}

In 1989, the disintegration of the former Republic of Yugoslavia commenced with violent secessions for independence. By 1995 , Bosnia and Herzegovina $(\mathrm{BiH})$ and Croatia became independent, as nationalistic movements led to the creation of independent states. Internationally, $\mathrm{BiH}$ and Croatia were recognized in 1992. Later that year, both countries joined the international community, with acceptance into the United Nations (see
Klemencic and Zagar, 2004; Oluić, 2007; Rogel, 2004). Post-conflict, the former Republic of Yugoslavia is now seven independently politically sovereign countries. Of the seven newly formed nations that once comprised the Republic of Yugoslavia, this work focuses specifically on $\mathrm{BiH}$ and Croatia because each country has taken a slightly different approach to their tourism endeavors. Both countries were devastated by the conflict that broke apart the Republic of Yugoslavia. Physically, the 
countries are different because Croatia has the Adriatic Sea while $\mathrm{BiH}$ for the most part is landlocked, with the exception of a small amount of land extending to the sea. These two countries also make this study unique due to their simultaneous histories of conflict, and as this paper develops the modes of discourse examined (re)construct each country's image.

The outline of this paper begins with the conceptual three-fold typology being presented and applied to this research. Next, the literature review discusses memory, post-war tourism, discourse, and imaginative geographies. The following section details the interpretative methods used prior to going into the analysis segment. The section, (re)imaging landscapes through tourism, presents and reflects on the textual and visual content on $\mathrm{BiH}$ and Croatia to place these countries as case studies in the three-fold typology. The conclusion follows thereafter.

\section{Conceptual Three-Fold Typology}

This research will locate and display how contrasting types of tourism discourses have (re)created or (re)constructed the imaginative geographies of a country's post-war image and landscapes. The contribution being proposed in this paper is a three-fold typology to classify where countries fit, based on how they are perceived or communicated to audiences. Questions that influence the production of this research include: how does a country's presentation (re)present the country's unique places and landscapes? In addition, is the mode of discourse simply trying to eliminate references of the conflict in the landscape, focusing more on cultural and physical attributes? With these questions in mind, this research contributes to the growing literature on post-conflict countries, and multiple representations consumed vis-à-vis alternative discourses. The three typologies being proposed in this paper bring into context: landscape remembrance, fading memory, and replacing memory.

Landscape remembrance relates specifically to integrating or educating potential tourists directly about the events that transpired during the conflict (see for example, Clouser, 2009), or 'war tourism' as will be further described by McLaren (2001). This includes details of constructed monuments, important places, or manifested memorials seeking to designate reflections of war that envision the past. By imagining the war-torn landscape, future travelers are presented directly with how their imaginations of a place were constructed in the media. Therefore, the presented semblance of the landscape has not been significantly redeveloped and calmly stands as a symbol of remembrance to the conflict. The second typology is fading memory, which involves some recognition of a conflict but places more emphasis on the future as time elapses since a period of conflict; this is often times positioned between remembering and forgetting (see for example, Müller, 2002; O'Keeffe, 2007; Whitehead, 2009). Therefore, this typology represents transition, a medium that integrates the past and present, though redevelopments and investments attempt to fade previous violence to (re)construct alternative imaginative geographies of a place or country. A country will have to essentially go through fading memory, until the landscape being conveyed has been restructured and the memory of the conflict has been replaced. The final designation, replacing memory, involves phasing out the past while placing emphasis on the future, often highlighting physical and cultural amenities; some have referred to this as obliterating, removing, or erasing memory (see for example, Foote, 2003; Zuelow, 2009). Though the landscape may have previously displayed scars from the conflict, for marketing and presentation purposes, these communications (re)create images-fully moving away from the events that devastated the country's reputation by erasing negative legacies of conflict.

To put these typologies into perspective, $\mathrm{BiH}$ and Croatia were selected foremost because of the conflict during the 1990s, and they are increasingly becoming popular destinations. The conflicts during the early 1990s shaped many of the geographical imaginations and perceptions of the former Republic of Yugoslavia. These two countries were selected to show how imaginations of places are (re)constructed through discourse, and 
ultimately locate where countries fit into the proposed typologies. To reiterate, this work argues for the presentations through discourse. As this work will show, depending on the type of discourse $\mathrm{BiH}$ and Croatia are presented differently and similarly, establishing multiple imaginations of these places. As will be later detailed, the landscapes of $\mathrm{BiH}$ still show bullet holes that scar the façades of buildings and bombed out structures remain visible. On the contrary, Croatia is a country with a superior coastline; as investors develop, many are referring to this coastline as the new Riviera (Wickers, 2005). By applying a three-fold typology to this study, the objective of this research is to identify how $\mathrm{BiH}$ and Croatia are emphasized through discourse analyses from the period following the conflict to the present time.

\section{Literature review}

\section{Memory, Discourse, and Tourism}

To imagine the aftermath of tragic events, wars leave cities, towns, and rural landscapes devastated and shattered, sometimes in complete ruin (Bevan, 2006; Graham, 2004). According to Clouser (2009), "the power of a landscape can be seen in its ability to mold thoughts, evoke memories and emotions, reinforce and create ideologies, and to relay to the world the values and priorities of a place" (p. 7). In many instances, the media directs images of war-torn landscapes and a society of people attempting to restore order and rebuild to viewers around the world (Chesshyre, 2004). It is both visual and textual globalized intermediary discourses that mentally construct our perceived knowledge of places. During the time of conflict in $\mathrm{BiH}$ and Croatia, the media communicated scenes and stories from these wars. These broadcasts constructed the geographical imaginations during the period of conflict. Alderman and Campbell (2008) state: "the remembering of the past, particularly difficult pasts, is always a socially constructed and potentially contested process" (p. 342). Building on difficult pasts, war tourism is a form of tourism where visitors seek out a place where violent or tragic events have occurred. Some of this has to do with battlefield tourism or visiting a site that was made famous during a particular conflict (see Ashworth and
Hartmann 2005; Cooper, 2006; Figal 2008; Müller, 2002; Winter, 2009). Barthel (1996) discusses war and remembrance in regards to tourism and memory, and conceptually suggests that these sites are (re)created to present a window into the past (see in addition, Robertson and Hall, 2007; Whitehead, 2009; Winter, 2009). Similarly, Ashworth and Hartmann's (2005) edited collection provides detail and further insight with case specific studies that address war and the role of tourism for (re)imaging sites of conflict and violence.

Destination images are often times centered on marketing techniques that strategically highlight a place's significant developments, attractions, or even events that occurred in history (see Barthel, 1996; Cartier and Lew, 2005; Daye et al., 2008; Govers et al., 2007; HernándezLobato et al., 2006; Richards and Wilson, 2007; Ritchie and Crouch, 2003). An image is a vision, and depending on past events the images of certain destinations can be perceived negatively, these are impressions (see Hernández-Lobato et al., 2006; Sönmez and Sirakaya, 2002). According to HernándezLobato et al. (2006), a "tourism destination image is a mental schema developed by a tourist on the basis of impressions" (p. 345). As suggested, destinations rely on impressions and more importantly image. To combat our previously interpreted understandings regarding post-war countries, their images must be (re)constructed to present an appealing destination. Marketing a destination with a burdened reputation requires discourse (re)presentations to create (re)interpretations of a place to the international audience. However, when approaching a study on $\mathrm{BiH}$ and Croatia, images of the war may still be displayed on the surface in two ways: clearly depicted in the physical (constructed) landscape and mentally, through previously constructed imaginations of these places. Depending on how a place is presented will initiate the (re)development of knowledge and perceptions-attempting to alter both the physical and mental milieu a country (Winter, 2008). Much of these (re)presentations can be influenced through tourism and destination marketing: a strategy carried out locally (e.g. Binns and Nel, 2002; Lee et al., 2007), nationally (e.g. Goulding and 
Domic, 2009; Scarpaci and Portela, 2009), and regionally (e.g. Lunn, 2007; Murphy et al., 2007). By (re)creating space and changing the image of the country vis-à-vis visual and textual discourses, tourism becomes a method of attracting people to restore the economic progression that was halted during and after the conflict.

\section{Discourse and Post-War Tourism}

Michel Foucault theorizes the challenges and meanings of discourse (see Foucault, 1972). His broader conceptualizations are applicable to the geographic study of space and place, arguing that history plays a central role in the construction of meaning. As Foucault (1972) advocates, "historical conditions [are] required if one is to 'say anything' about it, and if several people are to say different things about it" ( $p$. 44). Likewise, Foucault (1972) also goes on to remark that "the conditions necessary if it is to exist in relation to other objects, if to establish relations to resemblance, proximity, distance, difference, transformation-as we can see, the conditions are many and imposing...It exists under the positive conditions of a complex group of relations" (p. 44-45). To expand on what Foucault (1972) is suggesting with relevance to history (see in addition Harris, 1978; Müller, 2002; Soja, 1989), as far as understanding contemporary perspectives situating geography, for the purpose of this research we must substitute 'object' with place (emphasizing the country for this purpose of this research) and 'it' being the place (country) under analysis. There have been numerous researchers concerned with post-war tourism, with case studies presented on countries such as Vietnam (Henderson, 2000), Cambodia (Winter, 2008), Montenegro (Vitic and Ringer, 2007), Guatemala (Clouser, 2009; Steinberg and Taylor, 2005), Japan (Figal, 2008), Lebanon (Kanso, 2005), and Germany (Guy, 2004) as examples from the plethora of literature. In the selection of examples provided, at the point in history when war was occurring, the time-period specific imagination of these countries was negatively constructed. Post-war, countries attempt to (re)create an image, but the effects of war on a country reiterate to the international community a sense of fear, and one would likely not imagine these countries as desirable tourist destinations.

8
As this research and other authors have argued, countries have used tourism as a method to rejuvenate their post-conflict landscapes and economies. Henderson (2000) for example, uses Vietnam as a case study, attempting to understand challenges Vietnam went through to transform its post-war landscapes into tourist spaces. Likewise, Okinawa suffered severe damage during World War II; post-conflict (present day) Okinawa is often viewed as a tropical destination (Figal, 2008). To highlight the imaginations communicated via past and contemporary perspectives, Guy (2004) describes to the reader what was going through his mind while his aircraft descended into Berlin's Tempelhof airport. The constructed image of Berlin reflects memories of war, as Guy (2004) reflects in his introduction:

"As I flew towards Berlin those contradictory
images flushed through my mind, along-side
stories lifted from my Time Out travel guide,
the pages of recent histories I had been
reading in anticipation of my trip, and
memories of many atmospheric films of the
city I'd watched and novels I'd read-World
War II epics, Berlin Wall escape thrillers,
Cold War spy dramas, and off-beat, art-
house riddles. As I descended from the
plane onto the tarmac at Tempelhof I could
not avoid looking at the city through the
prism of memories that made up my
imagined Berlin." (Guy, 2004, p. 75-76)

Guy's (2004) opening narrative captures and highlights the experience of traveling to a place that reflects multiple memories of a highly publicized place of conflict. As Guy (2004) interprets the tourist landscape, he finds significant value in the expressions, erasures, and scars that encapsulate present day Berlin; these memories create imaginative geographies.

\section{Imaginative Geographies}

While keeping in mind Foucault's (1972) theory on discourse and history, this research builds on the growing body of post-conflict and tourism literature. This research will analyze these converging issues from an imaginative geographical perspective. Additionally, this research seeks to determine if there are 
parallels or associations within the contexts of imaginative (re)constructions, using tourism presentations as the primary focus towards analyzing post-conflict countries. To address war and tourism, the notion of imaginative geographies, detailed as a theoretical and methodological extension of the sociological imagination (see Agnew and Duncan, 1989; Mills, 1959), presents a conceptual and interpretative focus on places and landscapes (Gregory, 1994; Lowenthal, 1999; Said, 1978, 2002; Tyner, 2009). To expand on and highlight the significance of discourse once again, Gregory (1994) states: "discourse refers to all the ways in which we communicate with one another, to that vast network of signs, symbols, and practices through which we make our world(s) meaningful to ourselves and others" (p. 11). Therefore, the idea of conceptualized imaginative thinking assists in constructing or presenting an image, identity, or nationhood (Cloke et al., 2004; Foster, 2003; Mills, 1959). Therefore geographical imaginations are constructed perceptions of how society critically envisions a place (Graham, 2006; Light and Young, 2009; Tyner, 2009).

To construct this idea of imaginative knowledge, we need to understand from a geographical perspective how regions, countries, specific places, and landscapes are envisioned. This is based on some grounded understanding, or a sense of what exists when imaginations of places are structured (Ley, 2006; Tyner, 2006). According to Tyner (2006) "it was often through the efforts of geographers that specific knowledges of distant people and places were produced" (p. 40). To expand on this idea, places are constructed by the events that have unfolded over time. Whether events are expressed through the media via images or textual accounts, these presentations act as intermediaries influencing how we see or imagine a place. In relation to Tyner (2006) focusing on the production of knowledge, Said (1993) says there is "a new urgency about understanding the pastness (or not) the past, and this urgency is carried over into perceptions of the present and future" (p. 7). Constructed knowledge consists of this vision of the past; therefore, post-conflict, the way places are envisioned in the present time period will likely be altered based on previous understandings, or as what Foote (2003) and Dwyer (2004) would interpret as a memorial legacy. To follow, Ley (2006) argues: "intellectual knowledge, like other social phenomena, emerges from the intersection of imagination, practice, and context" (p. 178).

\section{Interpretative Methods}

To build on the imaginative geographies that $\mathrm{BiH}$ and Croatia want to convey, a discourse analysis involving several topical newspapers supplied the bulk of the context for this research. Interpretative qualitative content analyses rely on some type of discourse (i.e. newspapers, magazines, websites, television or radio broadcasts), to gather meanings situated in what a message is attempting to convey (see Harwood and Garry, 2003; Lehtonen, 2000; Rose, 2003; Tribe, 2008). Therefore, newspaper articles are effective intermediaries because they textually communicate to readers a place, both directly and indirectly, creating both positive and negative imaging (see Pan and Ryan, 2009; Wise and Harris, 2010). In many instances, newspaper articles are often based on individual experiences of someone (the author or interviewee) who has traveled to the destination they are writing about. According to Smith (2001), this type of interpretative qualitative research relies on experience to understand productions and presentations of knowledges. To add to Smith (2001), Osborne (2001) emphasizes that people become aware of places through media analyses to further construct our imaginations of particular places. Concerning the scope and scale of the articles, authors interchangeably make reference to two directly noticeable scales: national and urban. Place specific references are presented by most of the authors to supply additional depth, assisting the conceptualizations of the proposed typologies.

Consistent with the method of this research, a broadly ranging host of newspaper articles were selected from international English (language) newspapers. The dates of the newspaper articles range from 1993 to 2009 (see Tables 1 and 2). The articles listed in Tables 1 and 2 were searched using LexusNexus with the intent of acquiring a broad 
range of articles, specifically searching postwar tourism and $\mathrm{BiH}$ or Croatia. Only newspaper articles that specifically dealt with both post-war tourism and made direct references to the conflicts of the early 1990 s were selected to be included in the results of this analysis. To extract meanings presented through textual discourse in qualitative research, interpretations of written content are utilized to understand what is being conveyed (Lehtonen, 2000). Based on the relevant content selected and presented in this paper, this research analyzes how each article selected presents the previous conflicts in relation to the context of tourism to support the proposed typologies. Direct quotes taken from the host of newspaper articles will be incorporated into this analysis to further emphasize how each country is presented. This type of presentation supports imaginative research and also gives readers the opportunity to imagine and conceptualize the abstractions and meanings that textual accounts provide.
In addition to the newspaper articles, a review of each country's official English tourism website homepage will provide supplemental interpretations regarding BiH's and Croatia's presentation to the international community. Displaying tourism opportunities via websites is presently the popular and rapidly expanding method of destination marketing (see O'Connor, 2004; Egger and Buhalis, 2008; Zheng et al., 2010). Websites will supply further context to the imaginative geographies of $\mathrm{BiH}$ and Croatia in a more contemporary perspective. Websites adequately present images and additional information to accommodate potential international travelers, adding a welcoming reception or sense of comfort. Often times, websites are more geared towards strategic marketing campaigns and emphasize positive attributes about a place to encourage visitors to come and explore the myriad of possibilities. Several academics have analyzed and interpreted

Table 1. Newspaper articles included in the analysis focusing on BiH

\begin{tabular}{|c|c|c|c|}
\hline Newspaper & Year & Author & Focus of the Article \\
\hline The Japan Times & 1999 & Humphries & $\begin{array}{l}\text { War torn landscapes and Sarajevo as } \\
\text { an "open-air museum" }\end{array}$ \\
\hline The Budapest Sun & 2000 & Le Bor & $\begin{array}{l}\text { A "new kind of tourism," and } \\
\text { envisioning Sarajevo and Mostar }\end{array}$ \\
\hline The Globe and Mail & 2001 & McLaren & $\begin{array}{l}\text { 'War tourism' and the future of tourism } \\
\text { in Sarajevo }\end{array}$ \\
\hline The Times & 2004 & Chesshyre & Old reports and new images \\
\hline The Sunday Times & 2004 & Clancy & $\begin{array}{l}\text { How the past burdens a places } \\
\text { reputation }\end{array}$ \\
\hline National Post & 2004 & Pucci & $\begin{array}{l}\text { Attractions and sites in Sarajevo that } \\
\text { provide insights into the past }\end{array}$ \\
\hline The Daily Telegraph & 2007 & Bell & $\begin{array}{l}\text { Visiting former war zones, old and new } \\
\text { history }\end{array}$ \\
\hline Los Angeles Times & 2008 & Frick-Wright & $\begin{array}{l}\text { Jahorina's transitions, from a tourist } \\
\text { spot to an army camp back to skiing } \\
\text { and new investments }\end{array}$ \\
\hline
\end{tabular}

Note: Only newspaper articles that specifically dealt with both post-war tourism and made direct references to the 
these popular discourses to address how places are marketing destinations (see for example, Alderman and Modlin, 2008; Buckley et al., 2008; Choi et al., 2007; Miller and Henthorne, 2006; Stepchenkova and Morrison, 2006). By looking at newspapers and websites, discourse presentations are acknowledged on two scales. Traditionally newspapers are intended for a specific audience'. Websites on the other hand, attempt to reach out to a broader audience. By analyzing these English (language) websites, these communications take on contrasting meanings, as will be acknowledged in the results. In addition to the discourse analyses, photographs from personal field visits will display the landscape to complement the textual analysis. Photographs add to the visual nature of geography (Rose, 2003) and greatly assist the textual accounts (Schwartz, 1996), adding to the imaginative framework of this paper. Finally, the conclusion will revisit Said (1993) to envision and discuss the future of tourism in these countries.
(Re)Imagining Landscapes through Tourism Building on Guy's (2004) reflection's (quote above) and his presented imagined geography of Berlin, the results section presents authors' textual accounts pertaining to how $\mathrm{BiH}$ and Croatia are presented through newspapers and websites. Present imaginative conceptualizations acknowledged about a country will coincide with the atrocities of the past. Perceptions of the war and conflicts that occurred in $\mathrm{BiH}$ and Croatia set the foundations for investigating (re)interpretations, to demonstrate how these country's images are presented to the international community. Newspaper textual accounts will supply the context for landscape remembrance and fading memory. $\mathrm{BiH}$ are attempting to integrate war and tourism, often describing the atrocities of war by applying several techniques that seek to educate visitors. Croatia has moved beyond the war, while attempting to down - play the conflict or fade memory of the war. Though talk of war and tourism are prevalent in the

Table 2. Newspaper articles included in the analysis focusing on Croatia

\begin{tabular}{|c|c|c|c|}
\hline Newspaper & Year & Author & Focus of the Article \\
\hline $\begin{array}{l}\text { The Washington } \\
\text { Post }\end{array}$ & 1993 & Rupert & $\begin{array}{l}\text { The economic significances of tourism, } \\
\text { describing the present and future } \\
\text { despite the recent past }\end{array}$ \\
\hline $\begin{array}{l}\text { The Washington } \\
\text { Post }\end{array}$ & 1994 & Yenckel & $\begin{array}{l}\text { A recovering tourism industry, with a } \\
\text { focus on Dubrovnik }\end{array}$ \\
\hline $\begin{array}{l}\text { Christian Science } \\
\text { Monitor }\end{array}$ & 1996 & Woodard & $\begin{array}{l}\text { Rebuilding Dubrovnik and the Croatian } \\
\text { coast to restore tourism }\end{array}$ \\
\hline The Jerusalem Post & 1996 & Rodan & $\begin{array}{l}\text { The devastation of war on Dubrovnik } \\
\text { and the rapid efforts to restore city } \\
\text { infrastructure }\end{array}$ \\
\hline Budapest Sun & 2000 & Pál & $\begin{array}{l}\text { The revival of tourism but lingering } \\
\text { reminders of conflict }\end{array}$ \\
\hline The Gazette & 2004 & Schaal & $\begin{array}{l}\text { Briefly identify past war sites, but go on } \\
\text { to emphasize the cultural and physical } \\
\text { landscapes }\end{array}$ \\
\hline Sunday Mercury & 2007 & Haywood & $\begin{array}{l}\text { Croatia now as a competitive European } \\
\text { tourism destination, but the past war is } \\
\text { still mentioned }\end{array}$ \\
\hline
\end{tabular}

Note: Only newspaper articles that specifically dealt with both post-war tourism and made direct references to the conflicts of the early 1990s were selected to be included in the results of this analysis. 
newspaper articles focusing on $\mathrm{BiH}$ and Croatia, this will be followed by an analysis of BiH's and Croatia's official tourism websites as replacing memory to support the three-fold typology framework.

\section{Bosnia and Herzegovina displaying Landscape Remembrance}

To combine the memory of war with the establishment of tourism, McLaren (2001), writing for The Globe and Mail highlights the effects that war had on $\mathrm{BiH}$, using the term 'war tourism.' The war of the early 1990s in BiH is heavily referenced in the newspaper articles. The public perception of $\mathrm{BiH}$ was often shaped by the reports people heard from CNN and BBC in the 1990s; those are dated insights according to Chesshyre (2004), reporting for The Times. Because of how $\mathrm{BiH}$ was presented, the country was seen as one of the last places in Europe people would visit. Humphries (1999) writing a special for The Japan Times describes the landscape:

"Things have changed, however since Dec. 14, 1995, when the hostilities ended with the signing of the Dayton Accords, Sarajevo has been recovering. It is a gradual process, because repair costs are so high and the damage was so extensive. Ninety percent of the glass in the city's buildings was destroyed. Bullet holes are everywhere, pock-marking buildings, fences, cars and homes. The city's few high-rise...loom like ghostly, darkened, burned-out shell. Unexploded mines are still a threat in some heavily damaged areas...[later adding, quoting a woman from the Sarajevo tourism office] although many of the museums have been damaged or destroyed, you should see and enjoy the large open-air museum that is Sarajevo."

Similar, but also in contrast, to Humphries' (1999) statement, Clancy (2004) describes BiH in The Sunday Times:

"Twenty years ago, it was host to the bold and beautiful at the 1984 Winter Olympics. Ten years later it was the devil's playground, where Serbs and Croats, Christians and
Muslims slaughtered each other...[the county was, quoting Paddy Ashdown] one of the last tourist destinations in Europe."

Tourism has been on the minds of Bosnians since the end of the conflict in 1996 when they opened a tourist office in Sarajevo (Humphries, 1999), envisioning future tourism (McLaren, 2001). The Daily Telegraph in their travel section ran a special on Sarajevo, focusing on undiscovered European cities:

"Sarajevo is one of them. For all sorts of reasons, mainly war related, travelers have been reluctant to go there... Now the dangers are in the past" (Bell, 2007).

In the same article, Bell (2007) goes on to mention:

"Former war zones are great places to visit. The prices are moderate, people are really pleased to see you, and so much new history has accumulated along with the old... and the war has given them new materials to work with...they do offer finely engraved shell castings and bullets ingeniously turned into ball point pens."

Bell (2007) expresses that post-war destinations offer a combination of old and new history catered with undiscovered cities, and especially at reduced costs. As mentioned in the quote by Bell (2007) above, remnants of the war are for sale in bazaars-as merchants acquire war paraphernalia they sell mementoes of the conflict.

What we see in $\mathrm{BiH}$ is a unique method to (re)create reflections of war, by leaving the landscape essentially as is-the war-torn landscape therefore projects remembrance. Legacies of the war and physical scars are ubiquitous across $\mathrm{BiH}$; unexploded mines, bullet holes, bombed out buildings, and the Red Roses are common in both urban and rural areas, shown in Figures 1 and 2. The city of Sarajevo displays a landscape of warmarked memorials. As McLaren (2001) describes Red Roses: 
“...bomb pits. They mark scars of an almost four-year siege (May 2, 1992 to Feb. 26, 1996)...Known as the Roses of Sarajevo, the red splotches now serve as miniature makeshift war monuments. For the foreign visitor in Sarajevo today strolling through the city's lively downtown core, every red splotch underfoot serves as an eerie reminder of the horrors this place has seen in the years since its 1984 Winter Olympic heyday. The Roses are, in effect, Sarajevo's memory of the war made manifest."

The Red Roses, highlighted around Sarajevo are impressions or scars where mortar shells struck the ground. According to Pucci (2004), writing for the National Post, Red Roses symbolize where someone had died. Initially painted red, much of the color of these makeshift monuments has faded (Figure 3). In addition, a majority of the popular pre-war tourist attractions suffered damage during the conflict and many were left as monuments of war. Several new monuments reflecting war in Sarajevo have been erected or informally designated. A bakery downtown was rebuilt where a mortar shell killed 17 waiting in line for bread (McLaren, 2001). The bus station in Sarajevo is described by Le Bor (2001) in the Budapest Sun as "charred and pockmarked by shellfire." Attracting many visitors, the tunnel dug under Sarajevo's airport assisted communications and helped move people and supplies in and out of the city during the siege. Part of the tunnel has been kept intact, and is now a tourist attraction and a family run museum (Le Bor, 2000; Pucci, 2004).

A sense of historical ambiance is also imagined in several articles. Clancy (2004) describes the cities of Sarajevo and Mostar as old and magnificent. Le Bor (2001) describes Mostar simply as:

"ravaged and beautiful, they have invented a new kind of tourism. Somewhat mordant, but undeniably poignant: visitors trek here to see where the bridge used to be."

People were curious after the war to see where the Old Bridge was, including its remnants in the river. Reconstruction of Stari Most (The Old Bridge) was completed in 2004 , eleven years after the bridge was destroyed by shellfire. The bridge reconstruction project was funded with both local assistance and international support to once again display the iconic symbol of Mostar (UNESCO World Heritage, 2009). A remnant, now a plaque, sits on the bridge as a memorial to remind tourists, with the engraving: 'Don't forget '93' (Figure 4).

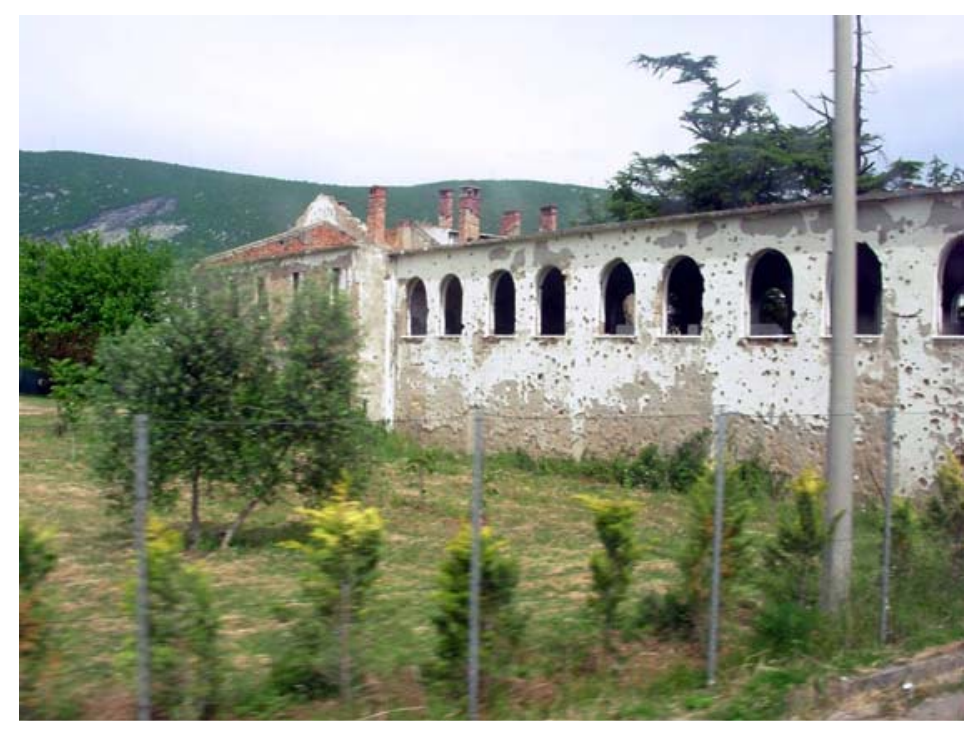

Figure 1. This building represents a legacy of the war from the early 1990s in Bosnia; this is a common depiction of the rural landscape along the bus route connecting Sarajevo, Bosnia and Herzegovina to Split, Croatia (Photo by author). 


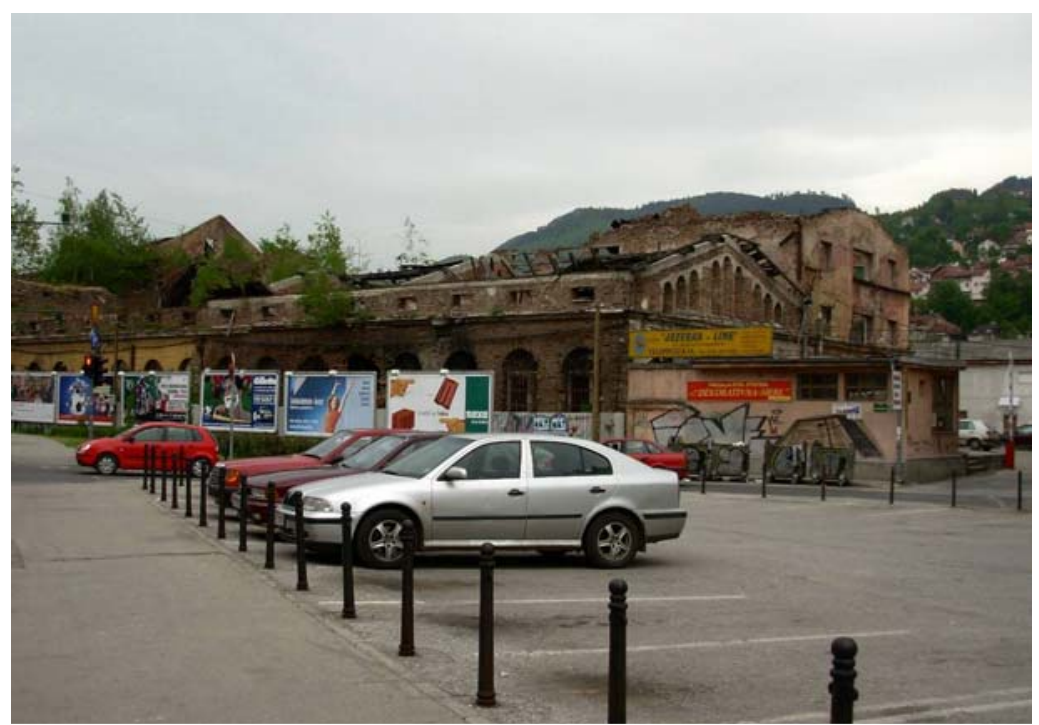

Figure 2. Downtown Sarajevo, war legacies of the urban landscape between the bus station and the river (Photo by author).

Shifting to a popular recreational destination in $\mathrm{BiH}$, the landscapes of the Jahorina ski resort depict legacies of war. The Jahorina Hotel, burned out and shelled during the conflict, displays significant scars, as discussed by Frick-Wright (2008) in the Los Angeles Times. Frick-Wright (2008) describes Jahorina:

"In the '80s, Jahorina was Yugoslavia's premier ski resort...hosting the women's skiing competition at the 1984 Olympics...Then the war started. Bosnian
Serb army leader Radovan Karadzic set up camp in the nearby ski town of Pale and led the 31/2 year siege of Sarajevo from Jahorina's doorstep. New additions to the resort were limited to the fortified bunkers and military compounds. The Sagging skeletons of those buildings still stand, starkly visible on the hill during the ride up the longest lift...In September 1995 an accidental fire in the hotel made several hundred refugees from Sarajevo homeless once again...the crispy frame of Hotel Jahorina remains."

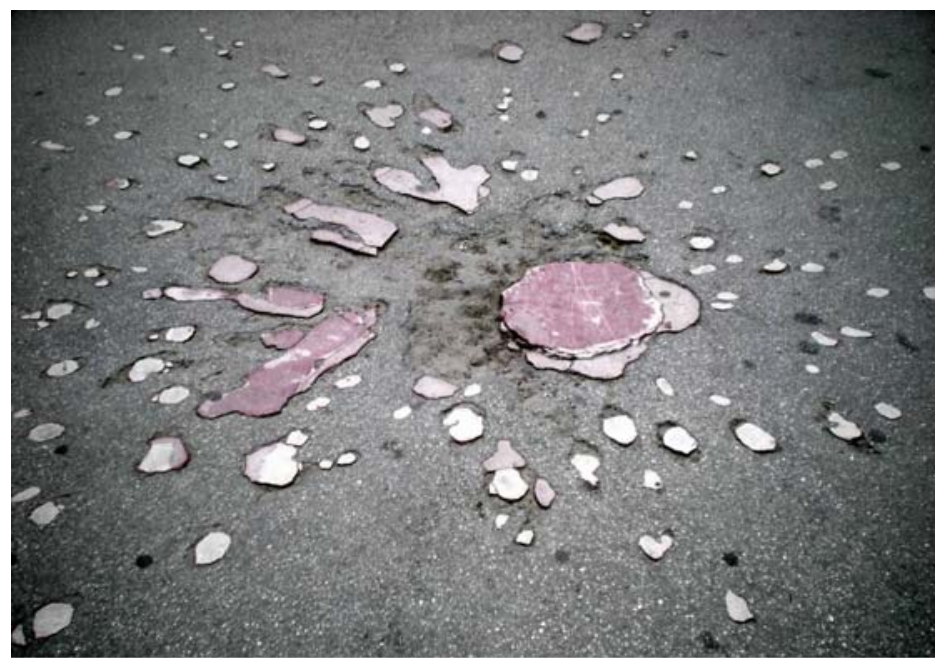

Figure 3. Red Rose of Sarajevo, makeshift monument of a mortar shell scar (Photo by author). 


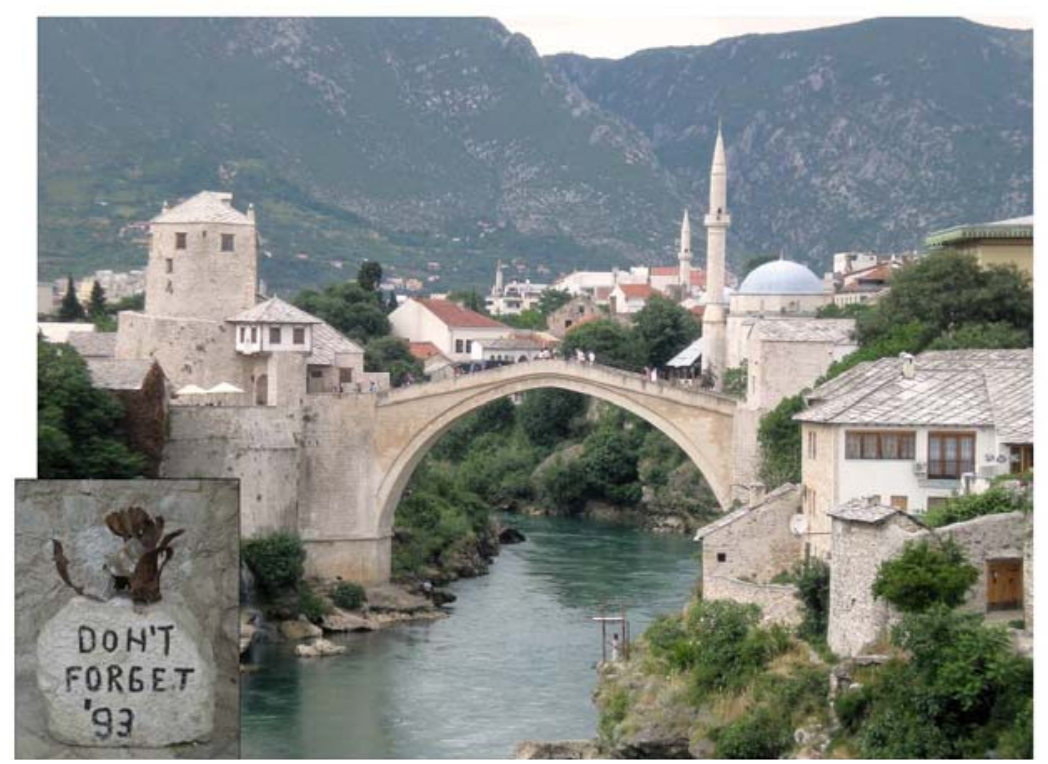

Figure 4. The restored Stari Most (Old Bridge) in Mostar, Bosnia and Herzegovina above (restoration completed in 2004). Bottom left, a piece of the original bridge symbolizing the year the bridge was destroyed (Photos by author).

However, Frick-Wright (2008) later finds that, due to the popularity of recreational skiing, private investors are interested in Jahorina. If individuals or corporations invest, and privatization becomes the next method for regenerating the war-torn landscape in $\mathrm{BiH}$, places around the country may likely enter a phase of fading memory before replacing memory

\section{Croatia's Fading Memory}

"Would anyone really want to go to war-torn Croatia? And just how safe is it? Although the strife continues in neighboring Bosnia, the new little nation of Croatia-which was created in the breakup of Yugoslavia-is hoping to again lure the tourist hordes that once flocked to its long, sun-swept Adriatic Coast. Just back from a week's trip, I found a grateful welcome" (Yenckel 1994, The Washington Post).

Croatia, in the early 1990s, was imagined as a land of war and deprivation. However, it is once again a country with a growing tourism reputation. Interestingly, Yenckel (1994), quoted above, is writing in the midst of the conflict in $\mathrm{BiH}$. The proximity of Croatia to $\mathrm{BiH}$ continued to burden Croatia's tourism industry in the early 1990s. Rupert (1993) and Yenckel (1994) both from The Washington Post, along with Woodard (1996) Christian Science Monitor, Pál (2000) The Budapest Sun, and Schaal (2004) The Gazette, highlight in their presentations of Croatia the devastating effects on the tourism industry suffered during the war years. This broad cross-section of articles ranging from 1993 to 2004 represents the devastations and legacies war inscribed on Croatia's image. Reason being, prior to the conflict, the tourism industry's importance was crucial for Croatia's economic sustainability. In their presentations of Croatia, the authors of these articles put a strong emphasis on (re)creating an image for the reader of what Croatia is like, by telling us about the past, but emphasizing the present and future.

The imaginative feel in Croatia is a sense of welcome, both nationally and locally. Locals are welcoming guests (tourists) to (re)establish their image. Pál (2000) mentions Croatia becoming a popular destination again by captioning a photo suggesting "tourists are flocking back to the sea," conveying to readers it is time to travel to Croatia again. 
Emphasizing Croatia as a desirable destination, Pál (2000) states:

"Hungarians are flocking to the Croatian coast in record numbers after deserting it as a holiday destination during the war years. After several bad seasons for the tourist industry, the Croatian coast of the Adriatic Sea is operating at full capacity again... The end of the war came in 1995 and this was followed by an aggressive marketing campaign by the Croatian Tourist Board as very few dared to spend their holidays in countries neighboring the Croatian-Serbian war zone..."The so-called 'Yugo effect' seemed to have a negative effect on us. If something bad happened in Bosnia or Kosovo, people generalized and associated it with the whole of the Balkans and were afraid to visit," said Martin Skenderovic, director of the Croatian Tourist Board in Budapest."

Pál (2000) and Yenckel (1994) identify, through efforts to (re)attract tourists to Croatia, the mid 1990 s was a period of reduced prices. Croatia is often presented as a desirable destination. Haywood (2007) from the Sunday Mercury emphasizes to readers images of Croatia past and present, along with projections of the future:

"the Mediterranean as it used to be. And therein lies the problem. Because as more holiday makers fall under the spell of this unspoiled destination, it will inevitably change and end up like everywhere else in the Med. The answer? Go before it is too late. Croatia-once part of Yugoslavia-was ripped apart by civil war in the 1990s. Now it is slowly rebuilding the tourism industry so vital to the republics economic future...Croatia, in fact, turns out to be a hidden gem with facilities as good as anywhere in Europe."

This quote is significant because Haywood (2007) mentions the term unspoiled. Though he does mention civil war, the idea conveyed to readers is a sense that the conflict is clearly over. He emphasizes that Croatia has restored itself to the prosperous times of the past. Though he suggests Croatia is unspoiled since 16 mass tourism developers have yet to arrive, he also warns that this will likely happen.

From a national context to a place specific perspective, Dubrovnik is often highlighted in many of the articles as a desirable (must-visit) destination due to its historical and aesthetic appeal. Yenckel (1994) describes Dubrovnik as "one of the world's great architectural treasures," reflecting a sense of heritage. Dubrovnik, in particular the towns 'old city,' was a target during the conflict. Since the end of the war, Dubrovnik's famed 'old city' has undergone major restorations. Rodan (1996), writing for The Jerusalem Post, mentions, "those who seek paradise on earth should come to Dubrovnik." Rodan (1996) draws parallels to Israel by describing Dubrovnik, as follows:

"Dubrovnik is the Croatian city along the Adriatic Sea that sustained heavy damage during the five-year war in Yugoslavia... The city was under siege for about 10 months, bombed daily by the Serbian-dominated Yugoslav army. But the Croats quickly rebuilt their homes and institutions... Today [referring to 1996, almost immediately following the siege and war], 90 percent of the infrastructure has been repaired..."We are like Israel trying to survive despite war and to keep on going" [quoting Croatia Tourism minister Nico Bulic]."

The reality of Dubrovnik is the visible scars and remnants of war in the landscape, including boarded up and bombed out buildings that were scarred by mortar shelling (Yenckel, 1994; Woodard, 1996). Figure 5 displays a plaque mounted on a side entrance to the old city of Dubrovnik. This plaque highlights remembrance of the conflict, similar to the 'don't forget '93' remnant in Mostar. While this plaque in Dubrovnik is a memorial to the siege of the city, it can be interpreted as an attempt to identify the impact of war without directly drawing the amount of attention that the bridge remnant in Mostar, $\mathrm{BiH}$ created.

Schaal's (2004) article is entitled Croatia's beauty and the beast: the lingering perception of war meets the reality of a stunning coastline, 


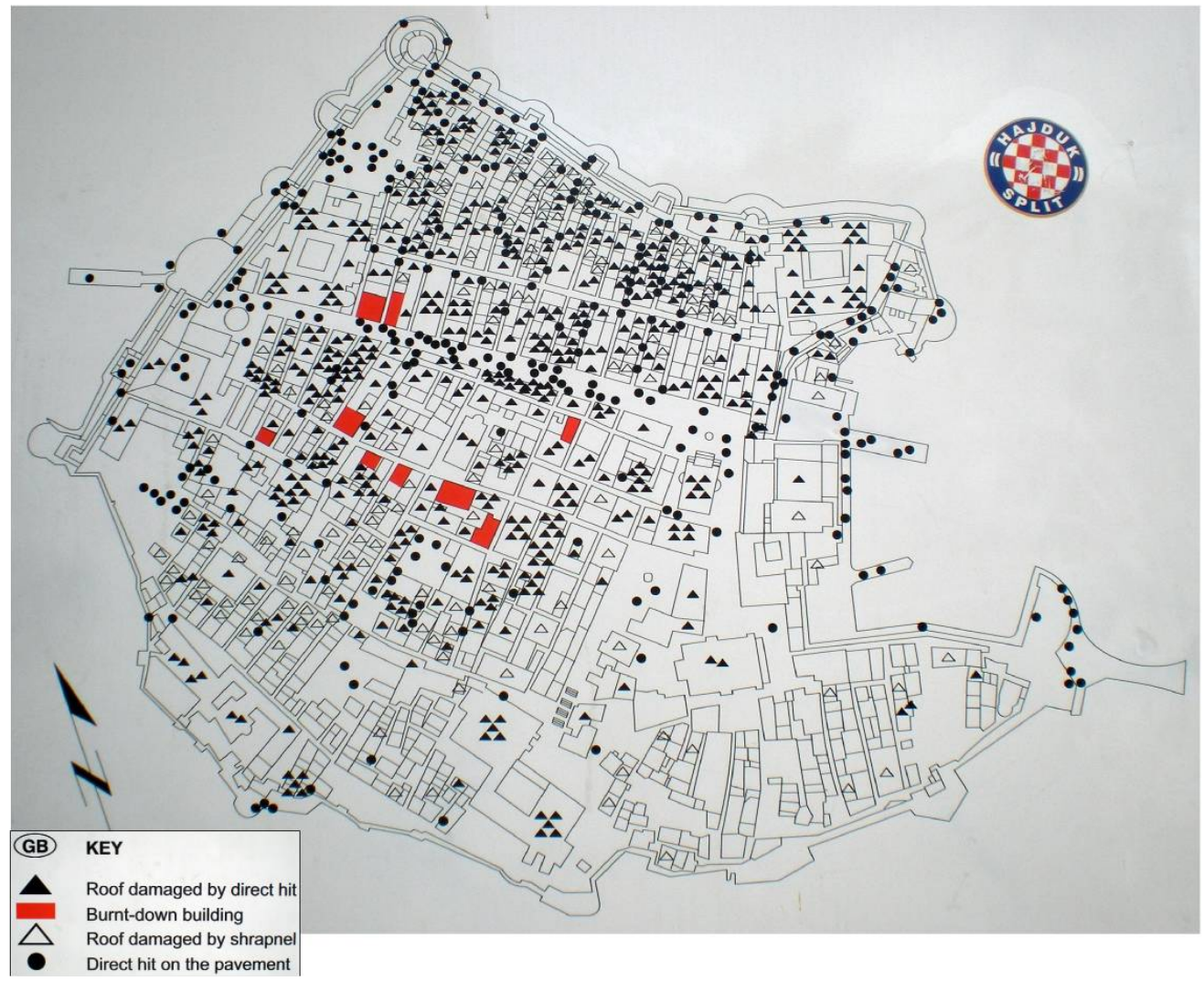

Figure 5. This plaque memorializes the conflict in Dubrovnik, Croatia (Photos by Author).

can be compared to Yenckel's (1994) article ten years earlier. The timing of these articles presents to us how presentations are similar and different over time and exemplify the concept of fading memories of war. Both authors build on constructed imaginations of the beast of war and the country's scenic architectural and physical beauty; they state:

"parts of Croatia are ready to receive tourists, although I suspect only the more intrepid will consider a trip until a lasting peace is attained in the region. The big allures, of course, are the country's rich array of historical attractions and the beautiful pristine beaches, coves and villages that dot the mainland and the many offshore islands. The islands and much of the coast were untouched by the fighting. But travelers with an intelligent curiosity also will be interested in the still-visible evidence of the war's fury" (Yenckel, 1994).
As the above quote assesses Croatia shortly after the war, the author focuses on historical and physical amenities, while a similar dialogue was written ten years later by Schaal (2004), as this author details:

"Croatia has nearly 2,000 kilometers of rugged, rocky shoreline along the Adriatic, with perhaps the cleanest waters in Europe. More than 1,000 islands dot the coast, their limestone cliffs...Zagreb, the Croatian capital, taking in its rich history and elegant $19^{\text {th }}$-century buildings, well-manicured parks, the vast, flagstoned public square and exuberant café society... Of course, the Balkan conflict ended nine years ago, but the perception of the region as a war-torn charnel house lingers in many people's minds. In fact, there are no remaining signs of war in Zagreb; only in the northern Dalmatia and along the eastern borderlands, the epicentre of the fighting, do you 
encounter bullet-strafed houses and the husks of bombed out buildings...After its total collapse during the war, tourism to Croatia has been making a steady recovery...Croatia has plenty to offer the adventure-seeker" (Schaal, 2004).

As described here, Schaal (2004) focuses on the positive images of Croatia, emphasizing and promoting the country's physical amenities, but without overlooking the conflict from nine years prior. The author describes the country as a place where people would seek to experience rugged coastal cliffs, clean waters, or visit some of the numerous coastal islands in the Adriatic Sea. Croatia is often depicted as a country of pristine beaches and scenic seascapes with numerous little villages (Figure 6 ). The islands of Croatia's Adriatic Coast are symbolized as places of retreat, generally untouched or unaffected by war (Yenckel, 1994).

The country continues to fade memories of the war into the past, choosing instead to emphasize Croatia's physical amenities and reconstructions. Eventually Croatia will replace memories of the war in the landscape. From a marketing perspective, moving towards what is discovered by analyzing Croatia's and BiH's tourism websites-both countries use this intermediary discourse to replace memory.

\section{Websites (Re)Presenting Images and Replacing Memory}

To apply the three-fold typology to interpretations of each country's official tourism website, both countries would now be categorized as 'replacing memory.' In an attempt to replace memory, there is a strong focus on contemporary situations and projections of the future. The pastness, to relate to Said (1993), is discouraged and elapsed in the website presentations due to BiH's and Croatia's relatively recent troubled past. Websites are quick and efficient, conveying images and presenting a place. Using websites to communicate images and information is becoming a standard marketing technique and is conveniently accessible

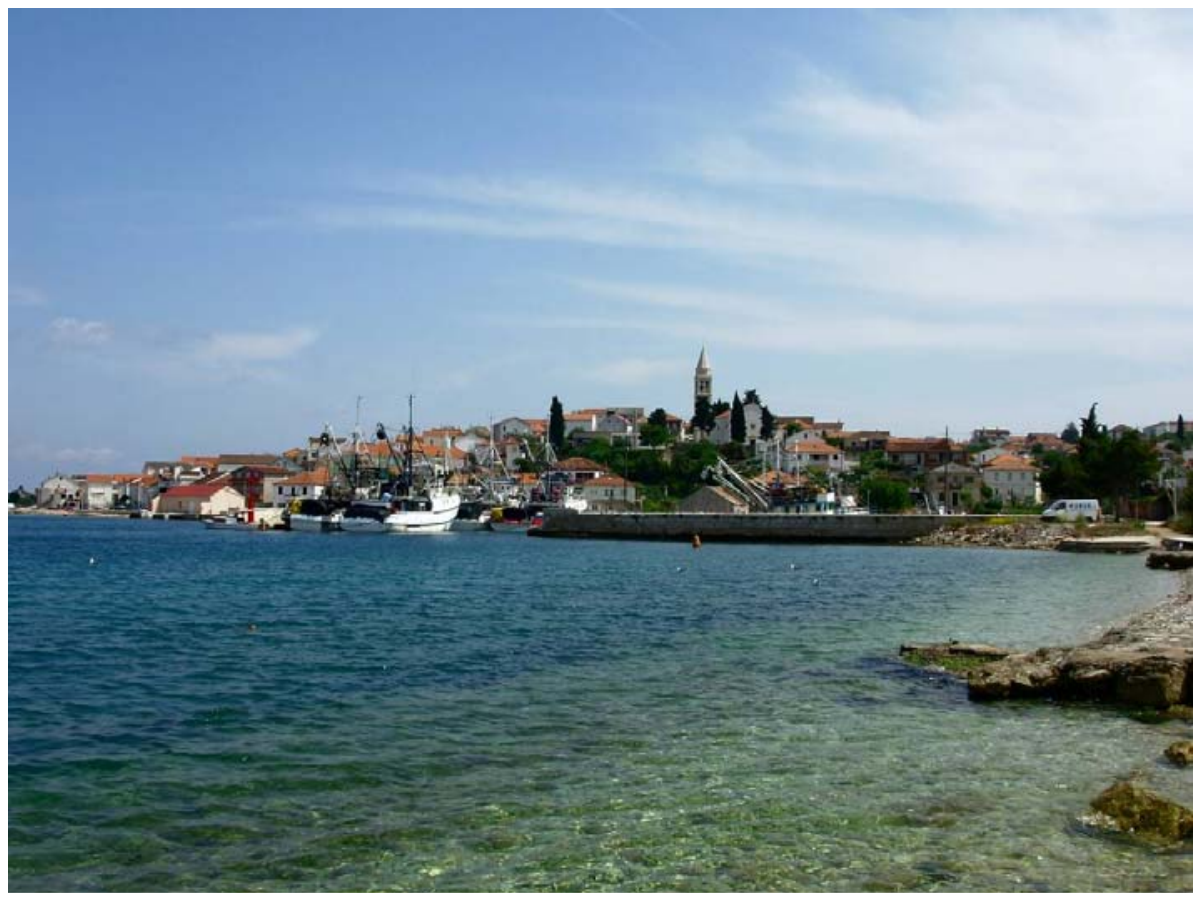

Figure 6. The islands off the coast of Croatia were generally untouched during the conflict (Yenckel 1994). Kali is a small fishing village on the Island of Ugljan; several boats each day connect visitors to Kali from Zadar (Photo by author). 
(Alderman and Modlin, 2008; Buckley et al., 2008; Stepchenkova and Morrison, 2006). Using this discourse, post-war countries can effectively (re)present their image to the global community.

For instance, $\mathrm{BiH}$ is replacing memory of the devastating hostilities to (re)construct the geographical imaginations of $\mathrm{BiH}$ to viewers around the world. The presentations directly on the BiH's tourism website attempts to remove these images and (re)present the country. To start, $\mathrm{BiH}$ romanticize the physical shape of their country's boundaries by describing 'the heart shaped land' (Tourism Association of Federation of $\mathrm{BiH}, 2010)$. They also use this romanticized phrase to bring to light their geographical location, stating: "Where are we?-The heart of SE Europe" (Tourism Association of Federation of $\mathrm{BiH}, 2010)$. $\mathrm{BiH}$ is marketing a peaceful display of affection in their national presentation. Though $\mathrm{BiH}$ was a country devastated by war in the early 1990s, this internet discourse focuses specifically on the country's physical advantages, traditional history, assorted architecture, and its geographic location where cultural realms overlap. There is a slide show of three photographs emphasizing the country's scenic aesthetics: rafting in one of the various gorges, a snow capped mountain, and grapes hanging from a vine. Other photos seem to express a youthful and active lifestyle, integrating the physical geography and scenic amenities, recreation, history, and cultural traditions. There are four photos that emphasize $\mathrm{BiH}$ as an eclectic destination, the titles and captions underneath the attention focusing photos by the Tourism Association of $\mathrm{BiH}$ (2010) include:

\section{"Your Next Adventure: Bosnia \& Herzegovina is one of the last undiscovered regions of the southern Alps. Vast Tracks of wild and untouched nature make it..." \\ "Sacred Crossroads: It is nearly impossible to decipher the many mystical influences that have merged on this tiny Balkan country..."}

"Bridging East and West: Few lands can boast as the ancient crossroads of modern European civilization. The Balkan peninsula itself is the bridge between Europe and Asia Minor..."

"Ancient Traditions: Experience Europe the way it once was. Old habits die hard in Bosnia \& Herzegovina preserving the ancient traditions of all the peoples of $\mathrm{BiH} . . . "$

Croatia on the other hand, emphasizes the greatness of the Mediterranean: "the Mediterranean as it once was" is the opening expression on Croatia's tourism website (Croatian National Tourism Board, 2010). This title reflects history-suggesting Croatia was a competitive destination prior to the wars of the early 1990s, (re)presenting that Croatia is now back once again to the country's prosperous times of the past, also mentioned by Haywood (2007). Cultural and physical attributes of the Croatian landscapes were displayed in a slide show presenting eclectic images of Croatia. The majority of the photos displayed cultural and physical landscapes, while others presented images of flora, fauna, agriculture, architecture, the arts, beaches, boats, food, and wines. Despite the fact that the war ravaged several of the urban and rural places in many of these photos, there were no true expressions of war landscapes in the photos, just aesthetics and amenities.

Textually, Croatia's website homepage greets potential travelers with a quote that symbolically creates a physical and cultural imagination of Croatia, the caption in bold reads "Land of diversity" and describes:

"This is a story of a land of a thousand islands, her magical nature and rich heritage, her great Men whose great deeds have forever etched the name of Croatia in large letters on the map of the world. This is a story about a land whose beauties have been celebrated since ancient times. From Cassiodorus, who wrote of the divine life led by Patricians on her shores, to Dante, who wrote his immortal verses, enthralled by the epic scenes of the blue expanse, and all the way to George Bernard Shaw, who found his paradise on Earth right here. Croatia has always been a place of true inspiration." (Croatian National Tourism Board, 2010) 
Other photos presented on the Croatia website's homepage mention current events and upcoming events in the near future. However, the wars of the early 1990s are not presented on Croatia's tourism website homepage either. What is presented is the history they want to communicate to potential tourists, that being Croatia's culture, heritage, and folklore. By marketing Croatia's unique cultural heritage and natural features, this gives potential travelers a well-rounded sense of what to expect when embarking on a journey.

What is gathered from both BiH's and Croatia's website homepages is the opportunity to navigate each country pre-departure. Each country strongly emphasizes current activities/events (e.g. festivals, recreational events), in addition to physical and cultural amenities. There were several unique characteristics displayed on each of the websites homepages. Both $\mathrm{BiH}$ and Croatia are attempting to cater to a broader audience by captivating and convincing potential travelers. Supplemental features allow prospective tourists to interact and explore the regions of country, find out the currency exchanges, current weather, or popular cuisine.

\section{Conclusion}

To relate back to Said's (1993) quote, there is "a new urgency about understanding the pastness (or not) the past, and this urgency is carried over into perceptions of the present and future" (p. 7). (Re)presented displays of tourism are relevant to the ideas of imaginative geographies concerning the past and present knowledge. Tourism is very much a part of the future in these countries, but we still need to consider the past, especially in how we are reminded of the past when critically analyzing tourism in a contemporary perspective. Ideally, this research serves as a base for studying and understanding post-war tourism and the redevelopments of landscapes, based on the presented three-fold typology.

The two modes of discourse textually analyzed, newspaper articles and websites, communicate different presentations. In reference to $\mathrm{BiH}$, the past is still reflected presently in the newspaper articles, detailing remembrance. The legacies of the war are not only seen in the landscapes but also expressed through tourism. Detailed accounts provided in the selected newspapers on $\mathrm{BiH}$ remind us of war, suggesting there is still very much a memory of war. Croatia, on the other hand, seems to be moving beyond the war, as the newspaper articles incorporated attempt to fade past memories of war by focusing on the future and using tourism as a catalyst for progression. So often the case, Croatia's focus seemed to be centered on moving forwards, with an emphasis on tourism being up some percentage from the previous year compared to the war years. Unique aspects surrounding Croatia's presentation is that it emphasizes the semblance of war as an event of the past, and then highlights Croatia now as a competitive destination.

Concerning $\mathrm{BiH}$ and Croatia, any remnants or reflections of the wars in the early 1990s were not displayed on the countries' official tourism websites. Investing in and promoting tourism encourages subsequent sustainable growth. $\mathrm{BiH}$ and Croatia's intensions are to also encourage tourists from outside the surrounding region to visit and see what their countries have to offer. The authors of the newspaper articles supply a historical context to educate their intended audience. Authors describe what occurred in the past and how the country is presently (at the time of the articles release) presenting their image, sometimes suggesting where they intend to go in the future. The websites, oriented towards a broader audience, focus on the present day. Presentations of $\mathrm{BiH}$ and Croatia on their tourism websites strategically do not relay images of the war-torn past to international audiences, a method of replacing memory.

\footnotetext{
'However, acquiring newspaper articles from around the world is becoming more widely available, though often limited to academic and institutional research search engines.
}

\section{References}

Agnew, J. A., J. S. Duncan (eds.) (1989) The power of place: Bringing together geographical and sociological imaginations. Boston: Unwin Hyman.

Alderman, D. H., E. A. Modlin (2008) (In)visibility of the enslaved within online 
plantation tourism marketing: A textual analysis of North Carolina websites. Journal of Travel and Tourism Marketing 25 (3/4), pp. 265-281

Alderman, D. H., R. Campbell (2008) Symbolic excavation and the artifact politics of remembering slavery in the American south. Southeastern Geographer 48 (3), pp. 338-355

Ashworth, G., and R. Hartmann (eds.) (2005) Horror and human tragedy revisited: The management of sites of atrocities for tourism. New York: Cognizant Communication Corporation.

Barthel, D. (1996) Historic preservation: Collective memory and historical identity. New Brunswick, NJ: Rutgers University Press.

Bell, M. (2007) Welcome to Sarajevo: this week Bosnia returned to the tourist map. The Daily Telegraph London, 31 March, pp. Travel 1

Bevan, R. (2006) The destruction of memory: Architecture at war. London: Reaktion Books.

Binns, T., E. Nel (2002) Tourism as a local development strategy in South Africa. The Geographical Journal 168 (3), pp. 235-247

Buckley, R., C. Ollenburg, Z. Linsheng. (2008) Cultural landscape in Mongolian tourism. Annals of Tourism Research 35 (1), pp. 47-61

Cartier, C., A.A. Lew (2005) Seductions of place: geographical perspectives on globalization and touristed landscapes. New York: Routledge.

Chesshyre, T. (2004) Ashdown backs Bosnia tourism. The Times London, 24 January, pp. Travel 4

Choi, S., X.Y. Lehto, A.M. Morrison. (2007) Destination image representation on the web: content analysis of Macau travel related websites. Tourism Management 28 (1), pp. 118-129

Clancy, T. (2004) Bosnia and Herzegovina. The Sunday Times London, 13 June, pp. Travel 4

Cloke, P., I. Cook, P. Crang, M. Goodwin, J. Painter, C. Philo (2004) Practicing human geography. London: Sage.

Clouser, R. (2009) Remnants of terror: Landscapes of fear in post-conflict
Guatemala. Journal of Latin American Geography 8 (2), pp. 7-22

Cooper, M. (2006) The Pacific War battlefields: tourist attractions or war memorials? International Journal of Tourism Research 8 (3), pp. 213-222

Croatian National Tourism Board. (2010) URL:http://www.croatia.hr/enGB/Homepage (Accessed on 18.06.2010)

Daye, M., D. Chambers, S. Roberts. (eds.) (2008) New perspectives in Caribbean tourism. New York: Routledge.

Dwyer, O. J. (2004) Symbolic accretion and commemoration. Social and Cultural Geography 5 (3), pp. 419-435

Egger, R., D. Buhalis. (eds.) (2008) eTourism case studies: management and marketing issues. Oxford: Elsevier

Figal, G. (2008) Between War and tropics: Heritage tourism in postwar Okinawa. The Public Historian 30 (2), pp. 83-107

Foote, K. E. (2003) Shadowed ground: America's landscapes of violence and tragedy. Austin TX: University of Texas Press.

Foster, J. (2003) 'Land of contrasts' or 'home we have always known'?: The SAR\&H and the imaginary geography of white South African nationhood, 1910-1930. Journal of Southern African Studies 29 (3), pp. 657680

Foucault, M. (1972) The Archaeology of Knowledge: And the Discourse on Language. New York: Vintage Books.

Frick-Wright, P. (2008) Bosnia's back in the snow biz; creaky lifts, so-so trails, landmines-and shrugs. It's all part of the charm at the Jahorina Ski Resort. Los Angeles Times Los Angeles, 14 December, pp. L6

Goulding, C., D. Domic. (2009) Heritage, identity and ideological manipulation: the case of Croatia. Annals of Tourism Research 36 (1), pp. 85-102

Govers, R., F.M. Go, K. Kumar. (2007) Promoting tourism destination image. Journal of Travel Research 46 (1), pp. 1523

Graham, S. (ed.) (2004) Cities, war, and terrorism: towards an urban geopolitics. Oxford: Blackwell Publishing. 
Graham, S. (2006) Cities and the 'War on Terror.' International Journal of Urban and Regional Research 30 (2), pp. 255-276

Gregory, D. (1994) Geographical imaginations. Oxford: Blackwell.

Guy, S. (2004) Shadow architectures: War, memories, and Berlin's futures. In Graham, S. (ed.) (2004) Cities, war, and terrorism: Towards an urban geopolitics. Oxford: Blackwell Publishing, pp. 75-92

Harris, C. (1978) The historical mind and the practice of geography. In Ley, D., M. S. Samuels (eds.) (1978) Humanistic geography: Prospects and problems. Chicago: Maaroufa Press, Inc., pp. 123137

Harwood, T.G., T. Garry (2003) An overview of content analysis. The Marketing Review 3, pp. $479-498$

Haywood, B. (2007) Med's hidden gem; but visit before it's uncovered. Sunday Mercury Birmingham, 4 November, pp. Features 49

Henderson, J. C. (2000) War as a tourist attraction: The case of Vietnam. International Journal of Tourism Research 2 (4), pp. $269-280$

Hernández-Lobato, L., M.M. Solis-Radilla, M.A. Moliner-Tena, J. Sánchez-García. (2006) Tourism destination image, satisfaction and loyalty: a study in Ixtapa-Zihuatanejo, Mexico. Tourism Geographies 8 (4), pp.343-358

Humphries, R. (1999) Two steps forward, one step back. The Japan Times Tokyo, 13 January, pp. Focus Page

Kanso, A. (2005) Reinvigorating the "Switzerland of the Middle East": How the Lebanese government can use public relations to reposition the country as a premier tourism destination. Journal of Hospitality and Leisure Marketing 12 (1/2), pp. 135-156

Klemencic, M., M. Zagar (2004) Ethnic diversity within nations: the former Yugoslavia's diverse peoples, a reference sourcebook. Dencer CO: ABC-Clio's.

Le Bor, A. (2000) Tourism breaths again in Bosnia. The Budapest Sun Budapest, November 16, pp. 6

Lee, C-K., Y-S. Yoon, S-K. Lee. (2007) Investigating the relationships among perceived value, satisfaction, and recommendations: the case of the Korean DMZ. Tourism Management 28 (1), pp. 204-214

Lehtonen, M. (2000) The cultural analysis of texts. London: Sage.

Ley, D. (2006) Places and contexts. In Aitken, S., G. Valentine (eds.) (2006) Approaches to human geography. London: Sage, pp. 178-183

Light, D., C. Young. (2009) European Union enlargement, post-accession migration and imaginative geographies of the 'New Europe': Media discourses in Romania and the United Kingdom. Journal of Cultural Geography 26 (3), pp. 281-303

Lowenthal, D. (1999) From landscapes of the future to landscapes of the past. Norsk Geografisk Tidsskrift-Norwegian Journal of Geography 53 (2/3), pp. 139-144

Lunn, K. (2007) War memorialisation and public heritage in Southeast Asia: Some case studies and comparative reflections. International Journal of Heritage Studies 13 (1), pp. 81-95

McLaren, L. (2001) After the siege: Five years after Sarajevo was released from the grip of war; Leah McLaren reports, visitors to the historied city will find a people and a land that is both battered and beautiful. The Globe and Mail Toronto, 10 January, pp. R9

Miller, M. M., T. L. Henthorne (2006) In search of competitive advantage in Caribbean tourism websites: Revisiting the unique selling proposition. Journal of Travel and Tourism Marketing 21 (2/3), pp. 49-62

Mills, C. W. (1959) The sociological imagination. Oxford: Oxford University Press.

Müller, J-W. (ed.) (2002) Memory and power in post-war Europe: Studies in the presence of the past. Cambridge: Cambridge University Press.

Murphy, L., G. Moscardo, P. Benckendorff. (2007) Using brand personality to differentiate regional tourism destinations. Journal of Travel Research 46 (1), pp. 514

O'Connor, P. (2004) Conflicting viewpoints on web design. Journal of Travel and Tourism Marketing 17 (2/3), pp. 225-230 
O'Keeffe, T. (2007) Landscape and memory: historiography, theory, methodology. In Moore, N., Y. Whelan (eds.) (2007) Heritage memory and the politics of identity: new perspectives in the cultural landscape. Burlington, VT: Ashgate, pp. 318

Oluić, S. (2007) Bosnia and Herzegovina: Identity, nationalist landscapes and the future of the state. New York: Columbia University Press.

Osborne, B. S. (2001) Landscapes, memory, monuments, and commemoration: Putting identity in its place. Canadian Ethnic Studies 33 (3), pp. 39-77

Pál, B. (2000) Sunny outlook for Croatian holidays. The Budapest Sun Budapest, 24 August, pp. 23

Pan, S., C. Ryan (2009) Tourism sensemaking: The role of the senses and travel journalism. Journal of Travel and Tourism Marketing 26 (7), pp. 625-639

Pucci, C. (2004) Bosnian capital shakes off war, welcomes tourists: a mix of cultures in a mountain setting. National Post ( $f / k / a$ The Financial Post) Don Mills, Ontario, 7 August, pp. PT5

Richards, G., J. Wilson. (eds.) (2007) Tourism, creativity and development. New York: Routledge.

Ritchie, J.R.B., G.I. Crouch (2003) The competitive destination: A sustainable tourism perspective. Cambridge, MA: CABI Publishing.

Rivera, L. A. (2008) Managing "spoiled" national identity: war, tourism, and memory in Croatia. American Sociological Review 73 (4), pp. 613-634

Robertson, I., T. Hall (2007) Memory, identity and the memorialization of conflict in the Scottish Highlands. In Moore, N., Y. Whelan (eds.) (2007) Heritage memory and the politics of identity: new perspectives in the cultural landscape. Burlington, VT: Ashgate, pp. 19-36

Rodan, S. (1996) Croatia: back on the tourist map. The Jerusalem Post Jerusalem, 6 December, pp. Features 24

Rogel, C. (2004) The breakup of Yugoslavia and its aftermath. Westport CT: Greenwood Press.
Rose, G. (2003) On the need to ask how, exactly, is geography "visual"? ntipode 35 (2), pp. 212-221

Rupert, J. (1993) Croat village at home in hotel; trapped by civilian war, nhabitants turn lobby into town square. The Washington Post Washington, DC, 12 June, pp. A18

Said, E. W. (1978) Orientalism. New York: Vintage Books.

Said, E. W. (1993) Culture and imperialism. New York: Vintage Books.

Said, E. (2002) Invention, memory, and place. In Mitchell, W. J. T. (ed.) (2002) Landscape and power. Chicago: The University of Chicago Press, pp. 241-260

Scarpaci, J.L., A.H. Portela. (2009) Cuban landscapes: heritage, memory, and place. New York: The Guilford Press.

Schaal, E. (2004) Croatia's beauty and the beast: The lingering perception of war meets the reality of a stunning coastline. The Gazette Montreal, 28 August, pp. J4

Schwartz, J. (1996) The geography lesson: Photographs and the construction of imaginative geographies. Journal of Historical Geography 22 (1), pp. 16-45

Smith, S. (2001) Doing qualitative research: From interpretation to action. In Limb, M., C. Dwyer (eds.) (2001) Qualitative methodologies for geographers: Issues and debates. London: Arnold, pp. 23-40

Soja, E. W. (1989) Postmodern geographies. London: Verso.

Sönmez, S., E. Sirakaya. (2002) A distorted destination image? The case of Turkey. Journal of Travel Research 41 (2), pp. 185-196

Steinberg, M., M. Taylor (2005) Public memory and political power in Guatemala's postconflict landscape. The Geographical Review 93 (4), pp. 449-468

Stepchenkova, S., A.M. Morrison. (2006) The destination image of Russia: from the online induced perspective. Tourism Management 27 (5), pp. 943-956

Tourism Association of Federation of Bosnia and Herzegovina. (2010) URL: http://www.bhtourism.ba/eng/ (Accessed on 18.06.2010)

Tribe, J. (2008) The art of tourism. Annals of Tourism Research 35 (4), pp. 924-944 
Tyner, J. A. (2006) The geography of Malcolm $X$ : Black radicalism and the remaking of American space. New York: Routledge.

Tyner, J. A. (2009) War, violence, and population: Making the body count. New York: The Guilford Press.

UNESCO World Heritage. (2009) Old Bridge area of the city of Mostar. URL: http://whc.unesco.org/en/list/946 (Accessed 12.02.2010)

Vitic, A., G. Ringer (2007) Branding postconflict destinations: Recreating Montenegro after the disintegration of Yugoslavia. Journal of Travel \& Tourism Marketing 23 (2-4), pp. 127-137

Wickers, D. (2005) A star is born. The Sunday Times London, 13 February, pp. Travel 7

Winter, C. (2009) Tourism, social memory and the Great War. Annals of Tourism Research 36 (4), pp. 607-626

Winter, T. (2008) Post-conflict heritage and tourism in Cambodia: The burden of Angkor. International Journal of Heritage Studies 14 (6), pp. 524-539
Wise, N., J. Harris (2010) Reading Carlos Tevez: Football, geography, and contested identities in Manchester. International Journal of Sport Communication 3 (3), pp. 322-335

Woodard, C. (1996) Tourists finally flock again to Croatia's sunny coast. Christian Science Monitor 88, September 4, pp. 196

Yenckel, J. T. (1994) Croatia: Would anyone really want to go to war-torn Croatia? And just how safe is it? The Washington Post Washington, DC, 22 May, pp. E1

Zheng, X., P. Bing, R. Law, D.R. Fesenmaier (2010) Assessing the visibility of destination marketing organizations in Google: a case study of convention and visitor bureau websites in the United States. Journal of Travel and Tourism Marketing 27 (7), pp. 694-707

Zuelow, E.G.E. (2009) Making Ireland Irish: tourism and national identity since the Irish Civil War. Syracuse, NY: Syracuse University Press. 